\title{
Det første møde
}

\section{Biblioteksmødet i 1909 set med eftertidens øjne}

Af Martin Dyrbye

\section{Prolog}

Dansk biblioteksvæsen har hyldet og lovprist overbibliotekar H. O. Langes foredrag afholdt på "et almindeligt dansk Biblioteksmøde" $i$ 1909. I 50 året for mødets afholdelse udgav Danmarks Biblioteksforening skriftet: $H$. O. Lange (1959), hvori foredraget aftryktes og rammet ind af bidrag om Lange, forfattet af fremtrædende biblioteksfolk fra folkebibliotekerne og forskningsbibliotekerne, nemlig daværende formand for Danmarks Biblioteksforening, R. Lassen; daværende biblioteksforeningsdirektør Robert L. Hansen og overbibliotekaren ved Det Kongelige Bibliotek, Svend Dahl. Mens Langes indsats fremhæves omtales biblioteksmødets øvrige drøftelser og resultater ikke. I Hvenegaard Lassens klassiske fremstilling De danske folkebibliotekers historie 1876-1940 (1962), udgivet af Danmarks Biblioteksforening, fremhæves også Langes foredrag, mens forfatteren ganske vist kort omtaler mødet i dets helhed, men uden at finde anledning til en uddybning. Samme tendens kan findes i Allerslev Jensens bog, "Til Bibliotekssagens Fremme" : trak af Bibliotekstilsynets virksomhed indtil 1970 (1985), der i høj grad bygger på Hvenegaard Lassens fremstilling. Endelig er biblioteksmødet omtalt og mere uddybende omtalt i festskriftet Det stcerke folkebibliotek, udgivet i 2005 af Danmarks Biblioteksskole og Danmarks Biblioteksforening $\mathrm{i}$ anledning af foreningens 100 års jubilæum. Men tendensen er den samme, nemlig fremhævelsen af Langes foredrags

Martin Dyrbye, Lektor, cand.mag. \& phil. E cand.scient.bibl.; Danmarks Biblioteksskole, Birketinget 6, 2300 Kobenhavn $S$ 
betydning for biblioteksudviklingen i Danmark; dog omtales de øvrige foredrags emner, men en egentlig længere og mere udtømmende fremstilling af begivenheden har der ikke været givet plads til. Markeringen af 100 året for afholdelsen af den første biblioteksudstilling og biblioteksmøde i Danmark ved udarbejdelsen af artikler herom råder bod derpå, og som resultat heraf foreligger nu en mere nuanceret og detaljeret undersøgelse af, hvad der egentlig hændte i den danske biblioteksudvikling i sommeren 1909. Nedenfor søges dette perspektiveret ${ }^{1}$.

\section{Indledning}

Den 3.- 4. august 1909, fandt det første danske biblioteksmøde sted i Århus. Denne begivenhed blev epokegørende på mange måder, og kom til at præge biblioteksudviklingen i de følgende årtier, ja faktisk helt op til vor egen tid, altså i et helt århundrede. Især ét bidrag fra biblioteksmødet har sat sine spor i biblioteksudviklingen og bibliotekshistorieskrivningen, idet $\mathrm{H}$. O. Langes berømte foredrag om "Bibliotekssagen uden for København" lagde grundstenen til den organisering af biblioteksvæsenet som vi kender det $\mathrm{i}$ dag.

Flere biblioteksfolk har senere bidraget på skrift om netop det ene foredrags betydning, mens mødet som sådan og dets betydning set som en helhed er knapt så vel belyst. Det søges der rådet bod på i det følgende, hvor biblioteksmødet gøres til genstand for en nærmere undersøgelse med henblik på at få klarlagt, hvorvidt det egentlig - bortset fra Langes foredrag - kan siges at have haft en mere varig betydning for biblioteksudviklingen.

Sidstnævnte spørgsmål er egentlig nok så væsentligt, idet tilsvarende møder afholdes i dag blandt danske biblioteksfolk. Ofte synes det umiddelbart vanskeligt ud fra en samtidig betragtning at gøre op, hvilke resultater der egentlig opnås, når fagfolk og særligt interesserede $i$ et fagområde mødes til fælles drøftelse og orientering om aktuelle problemstillinger på f. eks. et biblioteksmøde, et seminar eller til en kongres. Effekten og resultaterne af $\mathrm{f}$. eks. biblioteksmøder i dag kan være svære at gøre op, akkurat som det var tilfældet $i$ 1909. Det er oftere lettere for eftertiden, altså 100 år senere, at foretage en slags resultatopgørelse. 
En anden, men nok så væsentlig grund til at fokuserer særligt på netop det første biblioteksmøde er som antydet ovenfor, at dets betydning rakte videre end som sådan. Det blev faktisk normgivende for senere møder af lignende karakter, ja egentlig dannede det rammen om det, der siden hen skulle blive til en fast tradition $i$ dansk biblioteksvæsens historie, dvs. afholdelsen af mere regelmæssige møder, hvorunder bibliotekssagens støtter og interesser fik lejlighed til at drøfte aktuelle spørgsmål af både biblioteksfaglig og bibliotekspolitisk karakter.

Det første biblioteksmøde var præget af en entusiasme og særlig gejst, som må ses i lyset af bogsamlingssagens særlige stilling i 1909, hvor pionerånden $\mathrm{i}$ arbejdet med at udvikle bogsamlingerne til egentlige folkebiblioteker endnu var i sin vorden. Et enestående folkeligt engagement $\mathrm{i}$ bogsamlingssagen / bibliotekssagen karakteriserede mødet, men blandt deltagerne var også flere professionelle biblioteksfolk, som var karakteriseret ved at være præget af det, som første gang i dansk bibliotekshistorie på mødet blev betegnet med det anglo-amerikanske begreb "the library spirit". Dette begreb må forstås som en slags "kaldstanke", men det indebar også en særlig holdning til det at arbejde $\mathrm{i}$ et bibliotek i henseende til betjeningen af lånerne og troen på, at der lå en særlig mission i at udbrede læsning, sprede oplysning og viden til fælles bedste ${ }^{2}$.

Et andet interessant træk kan iagttages, nemlig den meget store lyst, som herskede blandt deltagerne til at drøfte endog mange spørgsmål i løbet af de kun to dage, der var afsat til mødet, og som udsprang af de foredrag, som tilhørerne havde lejlighed til at overvære. Talelysten var stor og formen uformel. Enhver blandt deltagerne, hvad enten de tilhørte bogsamlingssagens frivillige støtter, først og fremmest de ledende skikkelser blandt bogsamlingspionererne, eller hørte til blandt de uddannede, fik mulighed for at ytre sig og give deres besyv med, også med forhold, der ikke direkte vedrørte det emne, som var genstand for et foredrag med en efterfølgende diskussion.

Emnerne, som blev taget op, var mange, men i grove træk kan iagttages nogle særligt væsentlige områder, som påkaldte sig opmærksomhed og som set med eftertidens øjne 100 år efter, er 
interessante at hæfte sig ved. De drøftes stadig i bibliotekskredse, nemlig biblioteksteknisk-faglige anliggender, bibliotekspolitiske spørgsmål og endelig forhold omkring den helt overordnede organisation af det offentlige biblioteksvæesen i Danmark.

Det er hensigten i det følgende, at skildre dels omstændighederne i forbindelse med afholdelsen af det første danske biblioteksmøde i 1909, dels dets indhold og substans, samt vurdere dets betydning for eftertiden med henblik på at få besvaret spørgsmålet om, hvorvidt mødet overhovedet kan siges at have spillet en rolle for biblioteksudviklingen i dag.

Mødets enkelte dele, dvs. foredrag og diskussioner, behandles til dels summarisk med henblik på at fremdrage de væsentligste ting, som blev behandlet, mens læseren, der vil kende mere til detaljerne må henvises til at læse videre selv i det i øvrigt fuldt tilgængelige og aftrykte kildemateriale $\mathrm{i}$ form af gengivelser af foredrag og diskussionsindlæg.

Med andre ord: fokus i nærværende undersøgelse vil være kvintessensen af biblioteksmødet, som både i form og indhold må karakteriseres som banebrydende for videreudviklingen af de danske folkebogsamlinger til de institutioner, som i løbet af 1900-tallets 2. og 3. årti fik betegnelsen "folkebiblioteker".

Biblioteksbilledet anno 1909

og baggrunden for afholdelsen af det forste biblioteksmode

For at forstå baggrunden for afholdelsen af biblioteksmødet i 1909 opridses i korte træk de bibliotekshistoriske begivenheder, der få år forinden muliggjorde, at bogsamlings- og biblioteksfolk fandt anledning til at mødes med henblik på at drøfte bogsamlingssagens vilkår og fremtid i Danmark. Med udgangspunkt i biblioteksbilledet $\mathrm{i}$ dag rettes blikket tilbage til slutningen af 1800-tallet og tiden op til 1909.

Sammenlignes biblioteksforholdene i dag med biblioteksbilledet anno 1909 står det klart, hvor store fremskridt befolkningen har oplevet i løbet af et decennium i henseende til mulighederne for at få fri og lige adgang til en stor og alsidig materialebestand, adgang 
til tidsskrifter, blade og aviser, offentlig information, information i almindelighed og ikke mindst forskellige medieformer.

Biblioteksudviklingen har været præget af markante fremskridt i det 20. århundrede. Et af nøgleordene, der kan forklare årsagen til, at fremskridtene på biblioteksområdet for befolkningen i almindelighed har været så markante må søges $\mathrm{i}$ ordet organisationsudvikling.

I 1905 blev det første initiativ taget til at samle kræfterne blandt dem, der havde lagt sjæl og arbejde i det, som i samtiden blev omtalt som "bogsamlingssagen". Dannelsen af foreningen "Danmarks Folkebogsamlinger" var afgørende for en senere organisationsdannelse på biblioteksområdet. Etableringen af en forening til fremme af sagen var typisk for perioden, hvor en række andre områder i samfundslivet med rod i det folkelige foreningsarbejde blev organiseret gennem dannelsen af det, som i politologien benævnes interesseorganisationer. Bag foreningsdannelsen stod bogsamlingssagens pionerer, først og fremmest må her nævnes Andreas Schack Steenberg, som statens fremmeste repræsentant moralsk støttede tanken, og Jens Bjerre, som i sensommeren 1905 var den egentlige initiativtager til indkaldelsen af interesserede bogsamlingsfolk til stiftende generalforsamling i Fredericia den 25 . november samme år.

Støt og roligt bredte interessen for folkebogsamlingssagen. Antallet af bogsamlinger voksede, lige så det statslige tilskud, ydet siden 1882/83. Fra 1905 og i de følgende år nød folkebogsamlingerne stor bevågenhed $\mathrm{i}$ vide kredse, både lokalt og fra statens side, hvor foruden Steenberg, der var formand for den daværende statslige bogsamlingskomité, Det Kongelige Biblioteks overbibliotekar, H. O. Lange og overbibliotekaren ved Statsbiblioteket i Århus, sluttede op bag det folkelige engagement i bogsamlingssagen, som den benævntes i pionertiden.

I forbindelse med forberedelserne til den store landsudstilling i Århus i 1909 fandt bogsamlings- og biblioteksfolk sammen om, at fremme det, som navnlig H. O. Lange betegnede som "Bibliotekssagen" i Danmark ved at lade et biblioteksmøde afholde $\mathrm{i}$ forbindelse med udstillingen og i øvrigt også få etableret et synligt biblioteksfremstød gennem forevisningen af et udstillingsbibliotek i skala 
$1: 1$, et mønsterbibliotek, der kunne være et forbillede for udformningen af fremtidens folkebogsamlinger/folkebiblioteker.

Formålet med at indbyde til et biblioteksmøde for bogsamlingsog bibliotekssagens støtter var, at få samling på de forskellige aktører og hente gensidig inspiration til det videre arbejde gennem deltagelse i mødets forskellige foredrag, hvor ledende skikkelser præsenterede, hvad de aktuelt arbejdede med eller havde af ideer med henblik på den videre biblioteksudvikling i Danmark.

Udstillingsbiblioteket blev en stor succes, og i dagene 3.-4. august 1909 kunne bogsamlings- og bibliotekssagens pionerer med vinden i ryggen mødes til det første biblioteksmøde i Danmark. Ganske vist var det et usædvanligt skridt i en dansk sammenhæng, at indbyde til et biblioteksmøde, men forbilledet herfor er ganske klart. Både i Amerika og England havde der siden dannelsen af disse landes respektive biblioteksforeninger været afholdt regelmæssige biblioteksmøder, og fænomenet med at mødes i et fagligt forum var velkendt i Danmark blandt skolefolkene, hvor bl.a. Steenberg i sin egenskab af skole- og bogsamlingsmand havde deltaget i skolemøder.

Ideen til biblioteksmødet fremkom fra Statsbibliotekets side i 1908 og i løbet af det følgende års tid vandt den gehør i vide kredse blandt bogsamlings- og biblioteksfolk og deres ledere. Blandt sidstnævnte hørte de københavnske statslige bibliotekers repræsentant, H. O. Lange, Statsbibliotekets øverste chefVilh. Grundtvig, formanden for Statens Komité for Bogsamlinger, Andreas Schack Steenberg, Bibliotekarforeningen i København repræsenteret ved Raphael Meyer, de københavnske folkebibliotekers øverste leder, Vald. Vedel og endelig fra Foreningen Danmarks Folkebogsamlingers side, henholdsvis Jens Bjerre, Silkeborg og Johannes Grønborg, Rodskov pr. Løgten. Begge var lærere og gennem deres foreningsarbejde repræsenterede de det frivillige og folkelige bogsamlingsarbejde i Danmark ${ }^{3}$.

Tanken med afholdelsen af biblioteksmødet var, at bogsamlingsog biblioteksfolk fra hele landet skulle deltage, men pga. problemer med udsendelsen af programmet rettidigt var tilslutningen fra især København mindre end forventet. Til gengæld havde Steenbergs 
agitation for at skaffe deltagere fra "det øvrige land" virket efter hensigten og tilslutningen blev dermed "ret fyldig". 147 tilmeldte sig, hvoraf "dog en del sikkert ikke gav Møde", som det anførtes i mødeberetningen. Byer og købstæderne uden for København tegnede sig for den største tilslutning. Forklaringen på en mindre deltagelse fra hovedstaden end forventet skyldtes den omstændighed, at indbydelserne og programmet kom meget sent ud. Desuden deltog en repræsentant fra Sønderjylland og endog en deltager hjemvendt fra Amerika, frk. Anna M. Monrad ${ }^{4}$.

\section{Programmet}

På mødets første dag, tirsdag den 3. august 1909, bød Statsbibliotekets overbibliotekar, Vilh. Grundtvig velkommen, og glædede sig over tilslutningen, men beklagede samtidig, at "Deltagelsen fra København ikke var så stor som ønskeligt". Det at "de folkelige og videnskabelige Bogsamlingers Mænd" deltog i mødet var "noget af en Begivenhed", også taget i betragtning af deres forskellige interesser, men om deres fælles mål herskede ifølge Grundtvig ingen tvivl:

"Maalene og Midlerne er dog for en stor Del de samme. Alle virker vi eller bør virke for, at Bogsamlingssagen og Arbejdet for Oplysning gennem Biblioteker og Bøger maa naa en højere Udvikling $\mathrm{i}$ vort land end hidtil; vi er i den Henseende meget langt tilbage."

Programmet spændte vidt i løbet af de to mødedage. På førstedagen indledte Steenberg formiddagens møde med foredraget: "Hvor langt er vi komne og hvad nu?". På eftermiddagens første møde fik frk. Anna M. Monrad lejlighed til at berette om "Amerikanske Børnebiblioteker". Den første mødedag blev afsluttet med et foredrag af Grundtvig, "Om Uddannelse af Bibliotekarer". På 2 . dagen indledtes biblioteksmødet med Langes epokegørende foredrag; "Om Bibliotekssagen uden for København", og eftermiddagens møde omhandlede "En dansk Tidsskrift-Index", hvor Raphael Meyer oplæste den sygdomsramte Victor Madsens foredrag for tilhørerne. Herefter fulgte en omvisning på Statsbiblioteket forud for det selskabelige aftensamvær med middag for deltagerne og deres 
ledsagere. Efter foredragene var der diskussion blandt deltagerne, hvor adskillige af foredragsholdernes synspunkter blev drøftet indgående.

\section{Substansen $i$ biblioteksmødet}

Ved et tilbageblik på biblioteksmødets indhold kan, som antydet indledningsvis, tre overordnede temaer iagttages, nemlig diskussioner om biblioteksfaglige og -tekniske forhold, bibliotekspolitiske spørgsmål og endelig overvejelser om biblioteksvæsenets fremtidige organisatoriske udvikling. I det følgende skildres hovedtrækkene i indholdet af de diskussioner, som behandlingen af de tre hovedtemaer gav anledning til.Vægten i fremstillingen lægges hovedsageligt på de elementer i foredragene og diskussionerne, som fik en længerevarende betydning for biblioteksudviklingen og i særdeleshed $\mathrm{i}$ forhold til vedtagelsen af den første danske bibliotekslov i 1920.

De biblioteksfaglige og bibliotekstekniske forhold

En række biblioteksfaglige og -tekniske spørgsmål blev taget op på det første biblioteksmøde, akkurat som det er tilfældet $\mathrm{i}$ dag, når biblioteksfolk mødes til årsmøder i forskellige biblioteksfaglige fora. To tendenser gjorde sig allerede galdende i 1909. Dels berørtes spørgsmål, som angik bibliotekarens opgaver af faglig karakter, dels anliggender af mere teknisk karakter for så vidt de drejede sig om bibliotekernes indhold, altså materialerne, bestandssammensætningen, cirkulationstal, sammenhængen mellem f. eks. indeksering og formidling, samt udviklingen af børnebiblioteket, som var en ny bibliotekstype, der endnu i 1909 var i sin vorden.

\section{Uddannelse af bibliotekarer}

og sporgsmålet om deres fremtidige rolle $i$ dansk biblioteksvoesen

Et af de vigtigste emner for biblioteksmødet var spørgsmålet om fremtidig uddannelse på biblioteksområdet i Danmark. Det var Statsbibliotekets chef, overbibliotekar Vilh. Grundtvigs fortjeneste, at sagen blev taget op. Ganske vist i "skematisk Form", men som foredragsholderen anførte, var hans ærinde, at fremdrage "de vigtigste Punkter, der kunde afgive Holdepunkter for en Diskussion." 
Bibliotekaruddannelse var, som anført af Grundtvig, "det Punkt i Bibliotekssagen, hvor Tampen brænder." Alle "Grene af Biblioteksarbejdet" berørtes heraf, men Grundtvig pointerede, at dem han ønskede at tale til egentlig ikke var dem blandt de tilstedeværende, for hvem arbejdet i biblioteket allerede var "en Livsopgave eller Hovedvirksomhed". Der var tale om "en broget Skare, omfattende Mænd af næsten enhver Stand og Stilling, endnu kun faa Kvinder, lige saa broget som Mængden af Biblioteker i dette Land, hvor det er en Ærgerrighed for hver nok saa lille Sammenslutning at have sin "egen" Bogsamling."

Det var tydeligt, at Grundtvig ikke var ovenud begejstret for disse lægfolk, hvoraf de "allerfleste kommer til Virksomheden uden at have Forestilling om, hvad der kræves". De kastede sig dog måske alligevel over opgaverne med "Interesse og Energi" og løste dem "muligvis med Held". Deres manglende uddannelse blev måske afhjulpet ved brugen af $\mathrm{f}$. eks. Steenbergs bog, men "erstattes oftest med Indskydelser og egne "Opfindelser", som naturligvis kan træffe til at være gode." Kort og godt var der risiko for "unødigt Kraftspild, for Dilettantisme og for alle Autodidakters Fejl", og ifølge Grundtvig gik det "naturligvis rent galt" hyppigt.

Kravene til den gode bibliotekars kvalifikationer var efter Grundtvigs mening, at vedkommende skulle være i besiddelse af ordenssans, god håndskrift, sympatisk og hjælpsom, robust, taktfuld, ikke påtrængende over for publikum med hensyn til meninger og synspunkter, men samtidig "skulde han ogsaa være gennemtrængt af noget af den Aand, som besjæler Amerikas Bibliotekarer og maaske alt har gjort dets Biblioteker til, hvad der er: de føler sig og virker som Missionærer for en stor Sag, dragende, ansporende, agiterende." Desuden krævedes kendskab til litteratur og bøger, "Sporsans" og evne til at følge med i udgivelser, i realiteten for folkebogsamlingernes vedkommende, den dansk-norske litteratur, ikke blot "den underholdende, men ogsaa den oplysende og belærende."

Dertil kom at bibliotekaren skulle kende til en række "mere tekniske Sider af Biblioteksstyrelsen", men der ville også være "andre og vanskeligere Opgaver, som han nødig skulde møde helt uforberedt til", f. eks. "mulighed for Omordning og Udvidelse af 
Biblioteket, maaske med "aabne Hylder" og Læsestue", flytninger til andre lokaler eller "en ny Bygning, som vil kunne lempes efter Bibliotekets Tarv." Biblioteksarbejdet forudsatte brugen af kvalificeret arbejdskraft, og ofte ville det være afgørende, om der "paa Pladsen findes en energisk Mand, der har lidt Begreb om Tingene." En uddannet bibliotekar ville tillige betyde, at vedkommende "let kan komme til et andet Sted og et andet Bibliotek, hvor Forholdene er anderledes".

I foredraget påviste Grundtvig, hvor langt tilbage biblioteksudviklingen i Danmark i realiteten var i henseende til uddannelse af personale på bibliotekerne. Selvom hans foredrag primært var henvendt til de mange ildsjæle, som arbejdede i folkebogsamlingerne uden biblioteksfaglige forudsætninger, tyede han til at henvise til fagbibliotekernes personaleforhold i gennemgangen af de overvejelser han gjorde sig med hensyn til en fremtidig bibliotekaruddannelse. I en dansk sammenhæng kendtes kun til to lærebøger $\mathrm{i}$ biblioteksvæsen, dels Molbechs klassiske fremstilling fra 1829 og Steenbergs førnævnte bog. Danske forbilleder måtte derfor hentes i udlandet, hvor der f. eks. siden 1887 havde været afholdt forelæsninger "om egentlig Biblioteksvæsen og "Biblioteksvidenskab"” ved i Tyskland, på Universitet i Göttingen. I Berlin fandtes "to Skoler for kvindelige Bibliotekarer" og i England etablerede den engelske biblioteksforening kurser med eksaminer i 1884, mens amerikanerne fik deres første biblioteksskole i 1887. To årtier senere fandtes ifølge Grundtvig hele 10 biblioteksskoler i Amerika, hvoraf den ene havde specialiseret sig med henblik på uddannelse af børnebibliotekarer. I nordisk sammenhæng fremhævede Grundtvig de uddannelsesmæssige tiltag, som havde fundet sted i Norge og Sverige med hensyn til udvikling af bibliotekarkurser.

Fremadrettet foreslog Grundtvig, at der i Danmark etableredes "en rent praktisk Uddannelse, som bedst erhverves ved et mangesidigt og levende Bibliotek", f. eks. i tilknytning til seminarierne, fordi en meget stor del af bogsamlingsfolkene havde en lærerbaggrund. Imidlertid fandt Grundtvig ikke det som en realistisk mulighed pga. dårlige biblioteksforhold på seminarierne. Eventuelt kunne Statens Lærerhøjskole være en mulighed, men samtidig udelukkede Grund- 
tvig, at en uddannelse kunne etableres i samarbejde med hovedstadens biblioteker, dvs. Universitetsbiblioteket, Det Kongelige Bibliotek og de kommunale biblioteker. Derimod ville overbibliotekaren anbefale, at hans eget ansættelsessted, altså Statsbibliotek i Århus ville være velegnet, som "en naturlig Følge af dets Plan og Indretning", men samtidig tilføjede han "paa ingen Maade, fordi jeg ønsker en saadan Ordning, der som Regel kun vil volde os Ulejlighed."

Når Statsbiblioteket var bedst egnet som uddannelsessted hang det ifølge Grundtvig sammen med, at institutionen havde store udlånstal, også uden for Århus, og de åbne hylder med et stort antal bind repræsenterende "alle Emner", herunder et repræsentativt udsnit af bøger, som fandtes i "selv ret store folkelige Biblioteker", samt $\mathrm{i} ø v r i g t$ en rig repræsentation på de åbne hylder af dansk og udenlandsk skøn- og faglitteratur. Tilmed var læsesalen også velbesøgt og alt i alt var alle faciliteter i orden, således at Statsbiblioteket ville kunne imødekomme et ønske om at etablere en bibliotekaruddannelse i Århus.

I uddannelsen skulle eleverne gennem praktisk øvelse erhverve kundskaber om ekspedition "og et solidt Bogkendskab", foruden viden om bogfortegnelser og kataloger, indbinding og mærkning af bøger, teoretisk viden om biblioteksforhold i almindelighed gennem læsning af Steenbergs lærebog, samt ønskeligt, hvis der også "blev Tid til nogen Belæring om Bog- og Biblioteksvæsenets Historie og om Bogteknik." En længere uddannelsestid ville være ønskværdig, men under indtryk af de aktuelle forhold måtte man som minimum påregne "en Maaned med 5 à 6 Timers daglig Bibliotekstjeneste" og med maksimalt 3 deltagere ad gangen. Samtidig lagde Grundtvig vægt på, at uddannelsen kunne differentieres alt efter behov, og at den i øvrigt skulle være gratis.

Selvom der var elementer i foredraget, som kunne give anledning til løftede øjenbryn blandt tilhørerne, var diskussionen alligevel behersket. På vegne af Statens Komité til Understøttelse af Bogsamlinger lovede Steenberg, at han ville "søge at faa indført Bibliotekarundervisning ved Statens Lærerhøjskole i København", mens Lange, der jo repræsenterede Det Kongelige Bibliotek, var mere forbeholden over for Grundtvigs ideer. En uddannelse forud- 
satte først og fremmest, at de, der allerede var beskæftigede med bogsamlingsforhold blev aflønnet med en gage, som de kunne leve af. Han bakkede i øvrigt op om Steenbergs forslag, men fastslog samtidig, at København måtte være den ideelle placering for en uddannelse af 3-4 ugers varighed. I modsætning til Århus var de københavnske biblioteker ideelle med henblik på at knytte undervisningen sammen med en "Fremvisning af Biblioteksvæsen af højst forskellig Art." Synspunktet blev støttet af Raphael Meyer, som nævnte, at undervisningen skulle tilknyttes lærerhøjskolen, og "at den skulde rumme Mange mennesker paa en Gang". Samtidig ytrede han ønske om, at der dannedes en egentlig bibliotekarstand, som var forudsætningen for en "Løsning af hele vort Biblioteksvæsen".

Tanken om en sammenslutning af bibliotekarer i en stand blev fulgt op af inspektør Sachs, Købmandsskolen i København, som kun mente det kunne lade sig gøre i byerne, mens det var vanskeligt på landet, og derfor mente han, at tingene måtte adskilles. Dvs. at der måtte skelnes mellem "Uddannelsen af professionelle Bibliotekarer og Uddannelsen af Amatører." Den førstnæunte gruppe udgjordes af dem, der havde valgt "Biblioteksgerningen som Levevej", mens den anden bestod af frivillige ildsjæle, og tilføjede Sachs: "Men Tampen brænder, naar Talen er om Uddannelsen af Amatører: Mennesker, der driver Biblioteksvirksomheden som Bibeskæftigelse, som gør det, fordi de selv føler Lykken ved Læsning og ønsker at bibringe andre Interessen derfor." Disse mennesker burde forene sig eller deltage i et udvalg, der "søgte Tilskud fra Staten" med henblik på oprettelsen af kortvarige kurser $\mathrm{i}$ lighed med "Foreningen for danske Skolebørns Fællesleg", der efteruddannede lærere i "Lege og Boldspil".

En entydig opbakning til Grundtvig med hensyn til en eventuel placering af en kommende bibliotekaruddannelse i Århus kom alene fra pastor Hasselbalch, men alligevel drog overbibliotekaren på baggrund af diskussionen på biblioteksmødet den konklusion, at Statsbiblioteket efter hans opfattelse fortsat var bedst egnet som uddannelsessted. Samtidig medgav han dog, at der ikke var "noget i Vejen for Undervisning to Steder; Folk kan da selv vælge." 
I virkeligheden hang uddannelsesspørgsmålet også sammen med et andet dilemma inden for dansk folkebogsamlings- og biblioteksvæsen $\mathrm{i}$ begyndelsen af 1900-tallet, hvilket hang sammen med ovenstående problemstilling omkring de såkaldte "Amatører" og dem, der arbejdede professionelt, altså fik en aflønning for deres arbejde. I sit foredrag talte Steenberg om skellet mellem folkebogsamlingerne og de statslige biblioteker, og der fandt på baggrund heraf en drøftelse sted om bibliotekarernes rolle, deres opgaver og fremtidige virke i samfundet.

Hidtil var bibliotekarernes rolle og funktioner i forhold til folkebogsamlingerne uafklarede, mens de statslige og videnskabelige biblioteker gennem generationer havde haft ansat personale, som var lært op i varetagelsen af forskellige bibliotekariske funktioner uden dog for de fleste ansattes vedkommende at det betød, at de havde en formaliseret bibliotekarisk uddannelse. Målet for de statslige repræsentanter ved biblioteksmødet var, at få etableret et mere homogent biblioteksvæsen i Danmark, hvor lønnet og kvalificeret personale varetog opgaverne, hvad enten det drejede sig om arbejdet i folkebiblioteker eller de videnskabelige og statslige biblioteker. Der lå med andre ord en opgave $\mathrm{i}$, at bygge bro mellem de to bibliotekstyper.

Ifølge Steenberg fandtes en "Kløft" mellem "vore videnskabelige og folkelige Biblioteker", og han udtrykte håb om, at den "efterhaanden maa blive udfyldt". - Kløften svandt gradvis bort, og allerede kort efter det første biblioteksmøde afholdtes det første kursus i biblioteksvæsen for folkebogsamlingsfolk og lærere, og mere formaliseret indledte Statens Bogsamlingskomité i 1910 en efteruddannelsesvirksomhed med korte kurser. I 1918 oprettedes Statens Biblioteksskole og kimen var dermed lagt til etableringen af en egentlig bibliotekaruddannelse.

\section{Bestandsudvikling}

En af de meget afgørende faktorer for, hvorvidt et bibliotek er en succes eller ej er dets bestandsudvikling. Med dette menes alt lige fra materialeanskaffelser til formidlingen af disse, men også vedligeholdelsen, dvs. forholdet mellem indkøb og kassation. 
I sit foredrag benyttede Steenberg lejligheden til at kommentere spørgsmål omkring bogvalget, som siden dannelsen af foreningen Danmarks Folkebogsamlinger havde givet anledning til en heftig debat i foreningens talerør, Bogsamlingsbladet. I spørgsmålet om bogsamlingernes anskaffelsespolitik var Steenberg med sit dybe kendskab til det folkelige bogsamlingsarbejde pragmatisk indstillet, men det betød ikke, at han fandt det formålsløst at agitere for biblioteket som formidler af "Tankearbejde".

Lave udlånstal - dengang som nu - bekymrer biblioteksfolk. I 1909 hæftede Steenberg sig ved folkebogsamlingernes lave brugstal, som dels kunne forklares ved den kendsgerning, at mange lånere ikke var efterrettelige $i$ forhold til benyttelsen, dvs. ved ikke at tilbagelevere bøgerne rettidigt eller helt undlade aflevering, dels ved "Bogbestandens Beskaffenhed".

Det førstnævnte problem er klassisk i forhold til bibliotekernes daglige drift dengang som nu, og forskellige foranstaltninger er taget i brug for at sikre materialernes cirkulation. Problemet erkendtes blandt tilhørerne, men løsningen med brugen af "Mulkt", "bøder" eller "afgift" ved for sen aflevering kunne diskuteres. En tilhører fremhævede betydningen af, at en strafbetaling ved for sen aflevering kun virkede, hvis beløbet, der opkrævedes, ikke var for stort. Ellers ville truslen om en strafafgift ved for sen aflevering virke stik modsat og skræmme lånerne bort.

Den anden problemstilling, dvs. om bestandens sammensætning, var og er til stadighed et emne, som fra tid til anden giver anledning til diskussioner, ikke alene blandt fagfolk, men også hos lånere, forfattere og i medierne. For 100 år siden fremforte Steenberg en række punkter, som bogsamlingssagens pionerer måtte forholde sig til, deriblandt den kendsgerning, at mange bogsamlingers bestand hovedsageligt bestod "af saadanne Romaner, som Folk kun bryder sig om at læse én Gang, eller hvis Folks Læselyst og Læseævne er saadan, at de ikke læser en Bog - selv den bedste - mere end én Gang, vil der hurtigt i Bogsamlingen opsamles en Del "gamle" Bøger, der ikke laanes ud og altsaa sætter det gennemsnitlige Brugstal ned." En af udvejene for at løse problemet var ifølge Steenberg, at udlæste bøger cirkulerede blandt bogsamlingerne, 
men også indførelsen af det i samtiden nye opstillingsprincip med "aabne Hylder" ville kunne sikre, at "faa de "gamle" Bøger mere læste." - Som bekendt indførtes åbne hylder efter anglo-amerikansk forbillede med tiden og dermed eksponeredes materialerne på en anderledes og mere effektiv måde, end ved alene at formidle bestanden gennem katalogen. Desuden kunne bogsamlingerne udveksle titler med hinanden, og dermed udnytte bestanden bedre og medvirke til, at udlæste bøger fik en yderligere chance for overlevelse.

Som andre årsager til lave brugstal påpegede Steenberg, at konkurrencen fra anden side kunne forklare et lavt udlån. Også denne problemstilling gør sig galdende i dag, hvor bibliotekerne med rette eller urette kan frygte, at konkurrerende medier vil udhule brugen af traditionelle biblioteksydelser. I 1909 konstaterede Steenberg, at lånerne åbenbart tyede til at læse de forfattere, de var fortrolige med i forvejen, altså at "de uden synderligt Tankearbejde kan læse Bøgerne". Fænomenet - som i dag tilskrives det såkaldte "mindsteanstrengelsesprincip" - forklaredes med, "en vis aandelig Ugidelighed hos vort Folk, der ikke er blevet formindsket ved de Masser af Foredrag, der gennem Foredragsforeningerne styrtes ud over Landet”, og tilføjede Steenberg, idet han hentydede til et andet træk, som fortsat kan genkendes i dag: "Maaske staar det ogsaa i Forbindelse med en Selvgodhed, der svækker Interessen for andre Samfundslags og andre Nationers Liv." Også befolkningens "Mangel paa Ævne til at bruge Bøger" hæmmede ifølge Steenberg folkebogsamlingernes udlån.

I sin konklusion fastslog Steenberg, at de nære mål for fremtiden måtte være, at øge brugen af folkebogsamlingernes bøger; et bedre bogvalg, hvor både folkebogsamlinger og lånere var aktive; indførelse af "aabne Hylder"; oprettelsen af læsestuer på landet; et langsigtet mål, som de facto først endelig blev gennemført med biblioteksloven i 1964: "en fastere Organisation af folkebogsamlingerne ved Kommunalbestyrelsernes Deltagelse i Styrelsen og Samarbejde mellem nærliggende Bogsamlinger", herunder også "en større Udbredelse af Børnebogsamlinger.' Endelig fastslog Steenberg, at det nære mål først og fremmest var, at fremme arbejdet for, "at Læs- 
ning, Bøger og Bogsamlinger kommer langt stærkere frem i Folks Bevidsthed, som en Skole for Børn og Voksne, for lærd og ulærd."

I den efterfølgende diskussion var det især Steenbergs betragtninger om brugen af bøger, herunder den nye foreteelse med åbne hylder, som gav anledning til bemærkninger fra tilhørernes side, mens overvejelserne om en fremtidig kommunalisering af folkebogsamlingerne i realiteten kun anfægtedes af repræsentanten for Randers Haandværkerforenings Bibliotek, lærer Pedersen. Han argumenterede for det private foreningsbiblioteks eksistensberettigelse ud fra den betragtning, at lånerne her passede bedre på bøgerne, end det var tilfældet for "Byens Folkebibliotek". De to biblioteker havde samme størrelse, dvs. 2300 bind, og foreningen havde i øvrigt 1000 medlemmer, men modtog ikke, selvom det burde være berettiget til det, "hverken Stats- eller Kommunetilskud". Han fremhævede desuden, at "Folk faar her renere, pænere og bedre Bøger end i mange Folkebiblioteker, hvor de ofte afholdes fra at laane, fordi Bøgerne er saa snavsede", og om de åbne hylder konstaterede taleren, at de ikke stod for ham som "noget godt", men han tilføjede samtidig: "jeg kender dem ikke af Erfaring". Samtidig mente han, at lånerne alene valgte efter titel, ikke efter forfatteren, som de ikke lagde mærke til. Synspunktet om private foreningsdrevne biblioteker og deres berettigelse førte imidlertid ikke til diskussion på biblioteksmødet. Årsagen hertil må findes i den kendsgerning, at hovedparten af folkebogsamlingerne, hvoraf de fleste var oprettet i de mindre landsbysamfund, kun kunne overleve i kraft af stats- og kommunale tilskud, mens billedet i de større byer, f. eks. Randers havde større muligheder for at rumme private foreningsbiblioteker, der i kraft af deres medlemstal kunne klare sig selv.

Den principielle diskussion efter Steenbergs foredrag kom som nævnt altså til at dreje sig om "Kardinalpunktet", nemlig som anført af skoleinspektør Hansen, Hobro, "det danske Folks forhold til Bøger". Han uddybede synspunktet med følgende betragtninger:

"Vi lever i Grundtvigs Fædreland. Før hans Tid er Bøger misbrugte i en uhyggelig Grad. Naar Menneskene slap ud af Skolen, saa de aldrig en Bog mere, saa lede var de blevet ved dem. Derfor ivrede Grundtvig mod Bøger, men derved kom han i Grunden til at gøre 
Skade. Kun gennem det levende Ord skulde Paavirkningen ske, ikke gennem Bøger. Dette forhold maa ændres, og Forandringen maa komme fra Børneskolen. Over for de ældre er det vanskeligt at tage Opgaven op.Vi Lærere maa indrømme, at Forholdet til Børneskolen ikke er, som det bør være. Man bruger endnu for mange Steder Bøgerne som før Grundtvigs Tid - til Lektielæsning. Lærerne taler for meget i Skolen og vænner ikke Børnene til at bruge Bøgerne.Vi maa lære Børnene at benytte Bøgerne som gode Venner, hvorfra de kan hente Oplysninger. Kunde den danske Skole blot lære lidt af Udlandet her! Ved hver eneste Skole bør der være en Bogsamling. Mange Børn, især Drenge, har stort Mod paa at læse Personskildringer, som ikke maa være skrevet for Voksne, men kunne fattes og tilegnes af Børn."

\section{Udlånstal og kassation}

I diskussionen stillede en af folkebogsamlingssagens mest markante pionerer, lærer Grønborg, spørgsmålstegn ved sammenhængen mellem brugstal og bogsamlingernes indhold. Hans hovedsynspunkt var, at bogsamlingerne var "fyldt op med noget, som Folk ikke gider læse", herunder mange foræringer, forældede bøger, mens der dog endelig også var andre titler, f. eks. "Adam Homo", som kun udlåntes til "de mest udviklede læesere", men "saadanne Bøger maa vi have en Del af". Den kvalitetsbetonede litteratur var der plads til, men til gengæld ville han "anbefale den radikale Form at udskille alt det værdiløse og brænde det; thi forærer man det bort, kan det komme igen" og når "vi kun har gode Bøger, kommer Brugstallet nok op."

Tanken om, at kassere udlæste bøger ved at brænde dem blev kraftigt imødegået af de videnskabelige bibliotekers repræsentant, Raphael Meyer, som udtalte, at ingen "maa have Lov at brænde noget paa egen Haand", idet titlerne kunne indeholde værdifulde ting.

Heller ikke Steenberg brød sig om tanken om radikale metoder til kassation:"Man kan godt skille Bøger ud, der er blevet for gamle; men man maa ikke brænde dem; man kunde jo derimod lave et lille Musæum af disse gamle Bøger." 
Grønborg afviste, at det var hans tanke, at "man selv skulde brænde løs af Bøgerne", idet en kassation først skulle finde sted "efter Samraad med andre", og han forestillede sig især kassation af "de værste Røverromaner".

Diskussionen om kassation af bøger blev afrundet af Lange, som ikke mente, man skulle gemme på alle bøger, men "skille dem ud, som ikke har praktisk Betydning for den Befolkning, Biblioteket virker for". Samtidig understregede han nødvendigheden af omtanke med kassation: "Før man brænder en Bog, bør det undersøges, om den ikke fortjener at blive en Musæumsgenstand, fordi den i Forvejen savnes paa et af de store Biblioteker, der har den Opgave ogsaa at være Musæer." (s. 80)

\section{Genfinding og formidling}

På biblioteksmødet rejstes i øvrigt også spørgsmålet om, hvorledes befolkningen kunne finde frem til relevant litteratur, idet egentlige hjælpemidler hertil var stærkt begrænsede i en tid, hvor antallet af bøger anskaffet til folkebogsamlinger og bibliotekerne i øvrigt var stigende. Det var underbibliotekar Victor Madsen, som fik bragt dette spørgsmål op, men desværre måtte hans foredrag oplæses af Raphael Meyer, idet foredragsholderen var blevet ramt af sygdom. I foredraget talte Madsen varmt for, at der udarbejdedes ordentlige indekser til biblioteksvæsenet, egentlig først og fremmest med henblik på at lette genfindingen af tidsskriftartikler, som var ved at fă en stadig stigende betydning, men diskussionen efter oplæsningen af foredraget, viste at behovet for hjælpemidler til at finde litteraturen frem til lånerne var til stede.

Konsekvenserne ved ikke at have tilstrækkelige indekser, herunder en udbygning af datidens søgeredskaber, var åbenbare, idet lånerne $\mathrm{i}$ værste fald ville gå forgæves eller finde litteraturen andet steds end i folkebogsamlingerne og på bibliotekerne. Ganske vist gav Madsens overvejelser ikke anledning til større diskussioner under biblioteksmødet, idet deltagerne anerkendte vigtigheden af ordentlige indekser til tidsskrifter, men også bøger i det hele taget. Set med eftertidens øjne var det Victor Madsens fortjeneste, at 
indekseringsspørgsmålet blev gjort eksplicit og taget op for første gang i det nye biblioteksfaglige forum, altså biblioteksmødet i 1909.

\section{Åbne hylder}

Blandt dem, der talte varmt for de føromtalte åbne hylder, var Raphael Meyer. Han fandt, de gjorde biblioteket mere indbydende og dermed fremmede udlånet. Samtidig betonede han, at flere elementer kunne hæve brugstallet, f. eks. "ogsaa aabne Døre" kombineret med "Agitation gennem Aviser". Åbenhed og omtale i bladene af folkebogsamlingernes og folkebibliotekernes virksomhed blev i årene fremover vægtet meget højt, og indgik også i agitationen, debatten og diskussionen forud for vedtagelsen af den første bibliotekslov i 1920 .

Steenberg påpegede, at åbne hylder ikke var noget nyt, idet "Systemet gaar sin Sejrsgang i andre Lande", og dermed fandtes allerede et erfaringsgrundlag at gå ud fra. Han fik opbakning fra lærer Andersen, Lemvig, der var en varm fortaler for de åbne hylder, selvom han egentlig havde været skeptisk. Lånerne foretrak "som Regel nye Bøger, selv om de gamle er aldrig saa gode; men den uhindrede Adgang til Hylderne bevirker, saa vidt jeg kan skønne, at der kommer flere gamle Bøger ud." Et vist svind ved tyveri accepteredes. Nye bøger formidledes aktivt ved at lægge bøgerne frem på læsestuen, "hvor der intet Opsyn er, og hvor Folk uhindret kan gaa ind, og der er kun forsvundet et Par Stykker." Også børnene havde adgang til bøgerne gennem åbne hylder selvom der blev bragt "Uorden", men "den Fejl er let at afhjæelpe".

Lærer Petersen, Randers, var ikke overbevist om nytten af åbne hylder, som han mente besværliggjorde arbejdet for bibliotekaren, når denne skulle genfinde bøgerne efter at lånerne $\mathrm{i}$ givet fald kunne have bragt uorden $\mathrm{i}$ bestanden. Derimod fandt han det bedre, "at Folk har en Liste med 20-30 Bøger, som de ønsker" og åbne hylder kunne i stedet erstattes med kataloget, som lånerne skulle lære at benytte.

Med henvisning til erfaringerne med åbne hylder i Holbæk berettede Rasmus P. Nielsen, at man der måtte gå væk fra dem igen, hvilket han beklagede "i høj Grad". Årsagen var, at der ikke var til- 
strækkelig plads og "Hylderne skal indrettes derefter", men samtidig understregede han, at åbne hylder var "anbefalelsesværdigt, hvor det kan gennemføres."

Steenberg uddybede i sine afsluttende bemærkninger, at åbne hylder ikke overflødiggjorde kataloget, og han advarede imod at afskaffe det, idet "et virkelig beskrivende Katalog har en vejledende Værdi; Brugen af det kan give mere Udbytte end at gaa rundt og kigge i Bøgerne".

I dag er åbne hylder ikke længere et diskussionsanliggende i forhold til folkebibliotekerne. Det er vel snarere et spørgsmål om, hvorvidt den elektroniske fjernadgang til materialerne ikke på længere sigt betyder, at borgerne alene vil benytte biblioteket som et afhentningssted, mens det at gå rundt mellem reolerne og finde litteratur bliver sjældnere og sjældnere.

\section{Bornebiblioteksudviklingen.}

Blandt folkebogsamlingssagens pionerer fandtes en gruppe bibliotekskyndige, som rejste udenlands med henblik på at uddanne sig til bibliotekarer eller hente inspiration. Blandt dem hørte frøken Anna M. Monrad, som på biblioteksmødet holdt foredrag om "Amerikanske Børnebiblioteker". Hun hæftede sig ved konsekvensen i det amerikanske biblioteksarbejde. For amerikanerne var børnebiblioteker et vigtigt element $i$ en uddannelsesmæssig sammenhæng, og for "at Uddannelsessystemet ikke skal holde op med Barnets 14de eller 15de Aar, maa Biblioteket træde til." I den forbindelse måtte børnebiblioteker opfattes som "Afdelinger af det store Bibliotekssystem". Børnebibliotekernes funktion var ifølge Monrad, at fă børn til at læse "noget ordentligt, noget som har en blivende Værdi, som opvækker Sans for det ædle, milde og gode", selvom arbejdet hermed karakteriseredes som "svært".

Formidlingen var altafgørende, og ifølge Monrad havde børnebibliotekerne en særlig mission i at formidle god litteratur til børnene, frem for at nøjes med at tilbyde enten slette eller middelmådige bøger, f. eks. "Nick Carter-Litteraturen" og de såkaldte "Røverromaner". Formidlingsarbejdet skete især ved at knytte børnenes interesse for aktuelle begivenheder sammen med litteratur, 
som kunne uddybe emnerne, men også ved at bruge billeder som lokkemiddel. Som eksempel anførte Monrad følgende: "Da Jordskælvet paa Sicilien fandt Sted, blev alle tekniske og populære Bøger om Jordskælv lagt frem. Børnenes Opmærksomhed henledes paa gode Bøger gennem opklistrede Billeder, som forestiller, hvad Bøgerne handler om." Billedformidlingen var endog visse steder $\mathrm{i}$ Amerika sat i system, således at læreren i forbindelse med forberedelse af undervisningen kunne låne billedmateriale til brug for undervisningen.

Med hensyn til skønlitteraturen kunne den med fordel formidles uformelt gennem afholdelse af "Fortælletimen", hvor børnene kunne fă lejlighed til at mødes, og tilføjede Monrad: "Der er ikke mange Børn, som kan modstaa at komme til en Grimm- eller Andersen-Fortælletime. Naar de faar at vide, at flere Historier af samme Slags findes i den eller den Bog, og at de kan følge den samme Helt i andre Bøger paa Hylderne, er der straks en stor Efterspørgsel efter disse Bøger." Vigtigt var det at opbygge en "Smag for det bedste" hos børnene, og særlig fremhævedes lærerindernes indsats med afholdelse af "Fortælletimer" uden for skoletiden på biblioteket, gratis og målet var, når "Børnene vokser til", at udvikle dem til "Klubber", for: "Enhver, som har arbejdet med Drenge, kender den magiske Virkning, som det at høre til en Klub udøver paa en Dreng." Samtidig gav aktiviteter af den art mulighed for ikke alene at fa lejlighed til at læse "noget ordentligt, men ogsaa at lede et Møde efter parlamentariske Regler."

Vigtigt for Anna Monrad var betoningen af "det betydningsfuldeste Arbejde", dvs. samarbejdet mellem skole og bibliotek. I formidlingsarbejdet kunne biblioteket f. eks. sende læreren en liste over nye bøger, men også sørge for udlån til denne. Til gengæld havde læreren en pligt til at "opfordre Børnene til at ty til Biblioteket om hjælp." På grund af lange afstande til nærmeste bibliotek havde amerikanske biblioteksfolk udviklet et system, hvor bogkasser, et "Skab" med 25 bøger blev "leveret til et eller andet Hjem, hvor Børnene henter dem" og fortsatte skildringen: "Paa en bestemt Dag kommer en Assistent, som fortæller Historier. Hvert Barn faar Lov at tage en Bog med hjem. Der betales intet herfor. 
Biblioteket giver Bøgerne, og Damerne Arbejdet gratis.” På den måde lykkedes det, at få fat i børn "fra Negerkvarterer og fra Steder, hvor Husene kun er Skure." Også i sommertiden gjorde bibliotekerne en særlig formidlingsindsats ved forsøg med "at udlevere Bøgerne i de offentlige Haver og at holde Fortælletime i det fri". I modsætning til byerne, hvor det var "billigst at lave "Filialer",, kunne sådanne forsøg bedst betale sig på landet, hvor der var langt mellem husene. Desuden kunne Monrad berette om, at hun havde set en "Bogvogn, som køres af en Mand, der forstaar sig på Landboernes Behov" og som gjorde "stor Lykke".

Realiteterne i Danmark var imidlertid langt fra det idealbillede, som Monrad tegnede af de amerikanske børnebiblioteksforhold, men hun fastholdt, at man måtte "undersøge, hvad Kommunen trænger mest til, og hvilke Midler der passer bedst". Samtidig var hun overbevist om, at det ikke var tilstrækkeligt alene at have "store Biblioteker", men at man også sørgede for, at "Børnene bruger dem."

Foredraget gjorde lykke, og Anna M. Monrad modtog "Stærke Haandklap". Mødets dirigent, lærer Grønborg betegnede det som "heldigt", at tilhørerne fik "et Pust ude fra den vide Verden". I den efterfølgende diskussion bidrog Steenberg med viden om amerikanske biblioteksforhold, som han havde tilegnet sig ved selvsyn. Han henviste til, hvorledes danske seminarier kunne inddrage bogen i undervisningsøjemed på en praktisk og anvendelig måde efter amerikansk forbillede. Han havde bl.a. erfaret, at geografiundervisningen på en skole fandt sted uden brug af lærebøger, men derimod stimulerede børnenes egen tilegnelse af viden i faget ved at benytte sig af biblioteket som arbejdsredskab. Ifølge Steenberg var resultatet "særdeles godt". Hans bemærkninger blev fulgt op af $\mathrm{H}$. O. Lange, som talte varmt for, at børnebibliotekerne blev placeret $\mathrm{i}$ skolerne, og fremhævede én af de vigtigste pointer i Monrads foredrag, nemlig at amerikanerne indrettede særlige biblioteker for børn, fordi "de vil opdrage den fremtidige Borger tidlig nok i Brugen af Biblioteker" og tilføjede han: "faar et Barn den Vane at gaa hen til det offentlige Bibliotek, saa kommer den voksne Mand og Kvinde der ogsaa." 
En interessant bemærkning faldt fra Steenbergs side, idet han havde noteret sig, at det var almindeligt i Amerika med læsestuer for børn i skolerne, som også gjorde fyldest, når børnene havde mellemtimer i skolen, men "Børnene maa ikke gaa hjem; de sidder inde i Læsestuen og læser". Et andet interessant emne, som berørtes ganske kort, men senere fik en særlig betydning for folkebibliotekernes udvikling var tanken om oprettelsen af børnebiblioteker i folkebibliotekerne. Ganske vist førte diskussionen herom ikke vidt, men i realiteten var én af de tilstedeværende bogsamlingsrepræsentanter forud for sin tid i overvejelserne om børnebibliotekernes fremtid. Disse blev ikke medtaget i den forste bibliotekslov fra 1920, men ved lovrevisionen i 1931 indførtes ligestilling mellem lånerne inden for bibliotekets virkeområde, idet børnebiblioteksområdet blev taget med i loven. Fremover havde folkebibliotekerne pligt til at indkøbe børnebøger i sogne og kommuner, hvor der ikke fandtes et børnebibliotek i forvejen. Samtidig betød ændrede tilskudsregler, at selvstændige børnebiblioteker kunne oprettes.

I sin kommentar til Monrads indlæg talte lærer Højrup, Holbæk, varmt for indretningen af børneafdelinger "i det almindelige Folkebibliotek" eftersom "Grænsen mellem de Bøger, der læses af Børn og Voksne" ikke var let at drage". Når børnene var 14 år gamle forlod de fleste skolen og kunne dermed ikke længere låne bøger dér, og "saa kommer de til Folkebiblioteket, men de er dog kun Børn alligevel og bør derfor have Bøger fra en saadan Børneafdeling." Dertil kom, at også mange blandt forældrene ønskede "en Børnebog med hjem, som de kan læse højt af for deres Børn". I dag er det helt naturligt, at børnebiblioteket er integreret i folkebiblioteket og tilbuddet benyttes af både forældre, deres børn, skoler og daginstitutioner, som et helt naturligt led i opdragelsen og undervisningen af børn. Set med eftertidens øjne er det blandt andre Højrups fortjeneste, at børnebibliotekssagen blev en mærkesag i de følgende årtier, idet foreningen Danmarks Folkebogsamlinger og efterfølgeren Danmarks Biblioteksforening talte børnebibliotekssagen på talrige biblioteksmøder og årsmøder.

Set med samtidens øjne var opdragelsen af børnene i dagligdagen, herunder også skoleundervisningen, et anliggende for mød- 
rene, og derfor var det ikke unaturligt, at spørgsmålet om kvindens fremtidige rolle i bibliotekssagen netop blev drøftet i forlængelse af Monrads foredrag. Under den efterfølgende diskussion påpegede $\mathrm{H}$. O. Lange, at han gennem biblioteksbilleder fra Amerika havde noteret sig, at langt flere kvinder end mænd var til stede på amerikanske biblioteksmøder, og fandt, at flere kvinder i Danmark burde engagere sig i bibliotekssagen:

"Jeg tror, der er noget galt i den folkelige Biblioteksbevægelse, saa længe den hviler alene paa Mændenes Skuldre. Det har for meget andet at tage Vare. Naar vi faar Kvinderne med, faar vi Specialister, og det er det, der har givet denne Bevægelse den rivende Fremgang i Amerika. Jeg haaber, at de Kvinder, der er til Stede her, vil have Hjerterne aabne for vor Sag og gøre Propaganda for disse Idealer blandt danske Kvinder, saa haaber vi ogsaa her at faa Specialister."

Imidlertid var der ikke tale om, at kvinderne i Amerika alene bakkede bibliotekssagen op af idealistiske grunde. Som påpeget af Steenberg lå der "noget meget realistisk bagved", og fortsatte han:

"Mændene har ikke villet nøjes med den lille Løn, som Bibliotekarerne faar, og derved kom Kvinderne med og skaffede Sagen Fremgang."

Den store vision om den fremtidige organisering af biblioteksvoesenet i Danmark

På biblioteksmødets 2. dag, den 4. august 1909, fandt et af de mest epokegørende øjeblikke sted i den danske biblioteksudvikling, da overbibliotekar H. O. Lange holdt foredraget "Om Bibliotekssagen uden for København". I sig selv antydede emnet ikke, at talerens indlæg siden hen skulle vise sig at være mere end blot en status over tingenes tilstand, som de tog sig ud i 1909, men faktisk var en samlet og meget visionær plan for, hvorledes det samlede danske biblioteksvæsen burde organiseres med fremtiden for øje. Derfor er det første danske biblioteksmøde også med rette hovedsageligt blevet husket for eftertiden alene på grund af Langes foredrag. Det gælder således også i de bibliotekshistoriske fremstillinger af biblioteksmødets forløb, hvor der gennem tiden er skrevet meget om netop 
Langes fortjenester. I det følgende skal ikke føjes meget til, men snarere fokuseres alene på de elementer i foredraget, som med tydelighed kan siges at være udtryk for, at det vitterlig fik vidtrækkende betydning, at Lange i 1909 skitserede en samlet organisationsplan for det danske biblioteksvæesen ${ }^{5}$.

Foredraget rummer to hovedtemaer. Dels belyste Lange sammenhængen mellem læsning, uddannelse, demokrati, kultur og bibliotekerne, dels relationerne mellem bibliotekerne indbyrdes, dvs. organisationen af biblioteksvæsenet. Bindeleddet mellem de to dele er ordet oplysning. Netop ordene "oplysning", "uddannelse" og "kultur" indgår i dag i bibliotekslovens formålsparagraf, og i lyset heraf har Langes foredrag stadig aktualitet for nutidens biblioteksvæsen. I det følgende behandles disse to temaer med vægten på at drage paralleller til vor egen tid.

Temaet om lesning, uddannelse, demokrati og kultur

De indledende ord i Langes foredrag har således stadig gyldighed, idet han udtrykte følgende om forholdet mellem skolen, kulturen og samfundet:

"Et Lands Oplysningsbestræbelser og disses Udviklingstrin giver os en ganske god Maalestok for Landets Kultur. Skolens Udviklingstrin giver os et Billede af den Udrustning, som Samfundet ifører sine Børn, naar de drager ud i Livet, som, der baade skal udnytte og udvikle Kulturlivets Mangfoldighed. Skolen er Nøglen til Delagtighed baade i den aandelige og i den materielle Kultur."

Folkeskolen spiller i dag - som dengang - en fremtrædende rolle i samfundet. Læsningens betydning i uddannelses- og kulturpolitiske sammenhænge fremhæves til stadighed, idet ét af folkeskolens væsentligste formål er at lære børnene at læse og i det hele taget fremme læseevne og læselyst, som er blandt de vigtigste forudsætninger for videreuddannelse og deltagelse i samfunds- og kulturlivet. Da Lange holdt sit foredrag vakte det bekymring, at læseevnen ikke udnyttedes tilstrækkeligt efter skoletidens ophør, og kritisk anførte han, at selvom samfundet lagde vægt på, at alle lærte at læse, så "bekymrer det sig ikke om hvorvidt denne Evne, der jo dog kun er som en Adgangsbillet til et forjættet Land med de største Mulig- 
heder for aandelig Berigelse og kulturel Vækst, udnyttes, og hvorledes den benyttes. Gang paa Gang forbavses man over, hvor slet man selv i Krese, hvor man taler højt om sin Kultur, benytter sin Adgang til Læsning, og store Dele af vort Folk læser overhovedet ikke efter Udgangen af Skolen undtagen maaske en Avis med mere end tvivlsom Aandsføde."

\section{Loselyst og demokrati}

Udgangspunktet for de fremtidige folkebiblioteker skulle ifølge Lange være det, som kendetegner "et moderne demokratisk Samfund", nemlig "Borgernes Oplysning, Dømmekraft, Ansvarsfølelse og Moral". Demokratiets væentlige opgave var netop at bekæmpe "Uvidenheden og de sløvende og demoraliserende Indflydelser, som Nutidens Liv er saa rigt paa". Bibliotekernes opgave var her også at "udruste de brede Lag med Kundskaber for Livet, med det Forhold til Kundskabens Rige, der giver den stadig fornyede Tørst efter Kundskab og den altid dybere og ærligere Respekt for Kundskab". Kundskaben anså Lange for "en Livsbetingelse for Demokratiet". Med andre ord: et af målene for bibliotekerne var, at understøtte demokratiet, akkurat som det var tilfældet i England og Amerika. Samtidig var det vigtigt, at biblioteksvæsenet og bibliotekarerne var $\mathrm{i}$ besiddelse af den rette ånd og holdning til biblioteksarbejdet.

Det førnævnte begreb "the library spirit" udsprang ifølge Lange af "Bevidstheden om, at Demokratiets indre Berettigelse beror på Befolkningens stadige Vækst i Kultur, i Moral, i Samfundsforstaaelse og i national Bevidsthed", men samtidig måtte det erkendes, at "et saadant Syn paa Bibliotekssagen er endnu noget saa godt som ukendt herhjemme." Udviklingen skulle senere vise sig at gå i den retning, som Lange ønskede, og i dag hersker der bred politisk enighed om, at folkebibliotekerne er et vigtigt element $i$ et demokratisk kultursamfund og at de er medvirkende til at understøtte demokrati, kulturen, moral og etik og spredningen af viden om samfundsforhold.

Ud fra Langes perspektiv var bibliotekernes mission som spredere af læselyst $\mathrm{i}$ forlængelse af folkeskolens indsats for læsningen $\mathrm{i}$ 
almindelighed deres vigtigste opgave. Han fremhævede "Betydningen af god, sund og udviklende Læsning", som var den samme "baade i By og paa Land", men samtidig - og det skal ses i den historiske sammenhæng - troede han, at "Læselysten fødes naturligere og vokser sig stærkere paa Landet end i Byerne."

I en tid, hvor vandringen fra land til by var ved at forandre det danske landbrugssamfund til et industrialiseret land noterede Lange sig, at livet på landet "var roligere", idet "Livspulsen" ikke slog "saa hastigt og uregelmæssigt". Derimod bekymredes han over "Bylivet", der ganske vist "i visse Henseender kan være særlig befrugtende og ansporende for visse Naturer", men som også kunne rumme "en Rakke Farer for Aandslivets Trussel". Som eksempel nævnte han "Fabriksarbejdet", der "virker sløvende", men han var også bekymret over byernes "oftest tarvelige Forlystelser", betegnet som "spredende og fordummende paa Menneskene". Her er næppe nogen tvivl om, at Langes opfattelse, der i dag virker patroniserende og nedladende, var præget af hans egen virksomhed som aktiv i Blå Kors og Midnatsmissionen, hvor han i hovedstaden ved selvsyn gennem sin missionsvirksomhed havde mødt talrige sølle skæbner og stakler, og som påvirkede hans uegennyttige kristeligt betonede samfundsengagement, hvor han mente biblioteksvæsenet kunne udrette noget helt særligt $\mathrm{i}$ forhold til at udviske sociale skel:

"Bylivet i vore Dage frembyder en Række sociale Problemer af væsentlig moralsk Natur, der kræver den største Opmærksomhed og en Samvirken af alle gode Kræfter. Jeg er overbevist om, at her har det offentlige Bibliotek en overordentlig betydningsfuld Mission."

Udgangspunktet for Lange var det, som han benævnte den "moderne Biblioteksbevægelse", som havde sit udspring fra England og Amerika, og som havde "sat sig til Opgave at faa Folk til at læse", en "Oplysningsbevægelse", der var et "baade naturligt og nødvendigt Supplement til Skolen." Imidlertid konstaterede Lange, at bevægelsen endnu ikke havde nået Danmark, idet biblioteksvæenenet endnu ikke var organiseret. Desuden savnedes det, som "Amerikanerne kalder "the library spirit" (Biblioteksidéen)", som ikke havde "opfyldt Aandskulturens ledende i Kirke og Skole, 
i Litteratur og i Presse", og tilføjede Lange: "vore Myndigheder har endnu ikke set Opgavens Storhed og Vigtighed, hvorfor deres Bestræbelser heller ikke præges af Sikkerhed og Maalbevidsthed."

To ting i ovenstående er vigtige. Både Lange, forskningsbibliotekernes talsmand på biblioteksmødet, og Steenberg, folkebogsamlingssagens / folkebibliotekssagens fremmeste forkæmper, gik begge $\mathrm{i}$ brechen for, at den anglo-amerikanske biblioteksidé og-udvikling var så betydningsfuld, at danskerne kunne lære af den. De betragtede de anglo-amerikanske biblioteker som forbilledlige. Imidlertid har der efterfølgende været en tendens til at underkende disse ideers betydning for dansk biblioteksudvikling i det 20. århundrede, men også at "glemme" Amerikas betydning, idet der ofte alene henvises til "angelsaksiske" forhold alene, selvom de anglo-danske biblioteksforbindelser egentlig først for alvor gjorde sig gældende efter 1945. Det må slås fast, at de anglo-amerikanske biblioteksideer altså var fremme i folkebiblioteksbevægelsens pionerår, og at dansk biblioteksvæsens udvikling prægedes mere heraf, end vi måske som nation og småstat ønsker at indrømme. Uden Steenbergs og Langes betoning af begrebet "the library spirit", som altså også i 2009 kan fejrer 100 års jubilæum, ikke alene i Danmark, men også i Norden, har ganske sikkert bidraget til, at dansk biblioteksvæsen udviklede sig i samme demokratiske retning, som i Amerika og England, dvs. med betoningen af bibliotekerne som en vigtig del af det demokratiske samfunds udvikling, hvor fri, dvs. gratis, og lige adgang til bøger, information, viden og kultur var hovedhjørnestene i deres formål.

I forlængelse af den anglo-amerikanske tankegang gjorde Lange sig til talsmand for, at staten, der i forvejen understøttede de offentlige "videnskabelige Biblioteker" hævede statstilskuddet til folkebibliotekerne. Desuden fandt han, at kommunerne burde engagere sig i bibliotekssagen, og helt i tråd med den amerikanske model var argumentet herfor følgende: "... det er lige saa nødvendigt for et lokalt Samfund at have et offentligt Bibliotek som at have en offentlig Skole, og at de nødvendige Udgifter til Bibliotekets Drift bør kunne paalignes Beboerne med samme Ret som Udgifterne til 
Skolen." I England og Amerika sikredes tilskuddet fra det offentlige gennem bibliotekslovgivningen, og helt i samme ånd talte Lange for en dansk bibliotekslovgivnings vedtagelse på længere sigt. I lighed med Steenberg brød Lange sig ikke om, at folkebogsamlingssagen, der hovedsageligt var funderet i et i øvrigt uegennyttigt folkeligt engagement, førte til en slags "almissetænkning", hvor de fremtidige folkebiblioteker blev betragtet på samme måde som folkekøkkener. Om forskellen mellem folkebogsamlinger og folkebiblioteker anførte Lange:

"Folkebogsamlingerne er som en Almise til de brede Lag uden den rette folkeopdragende Kraft. Det offentlige Bibliotek skal jo ligesom Skolen opdrage Samfundsborgere, men i den Belysning tager Folkebogsamlingen sig ikke ud til sin Fordel."

Med andre ord: Lange advarede direkte imod etableringen af "Folkekøkkenbiblioteker", da han også argumenterede for, at Statsbiblioteket i Århus ikke alene skulle fungere som et landsdelsbibliotek, men også som folkebibliotek for befolkningen i Århus by, i stedet for at oprette et yderligere selvstændigt folkebibliotek, som måske ikke ville få tilført tilstrækkeligt med midler til at kunne opfylde de krav, som i fremtiden burde galde for folkebibliotekerne og fremmes gennem en bibliotekslovgivning.

Begge mål, altså indførelsen af en bibliotekslovgivning og en kommunalisering, blev ad åre realiserede. Biblioteksloven fra 1920 banede vejen for et statsligt og senere kommunalt engagement $\mathrm{i}$ bibliotekssagen. Med andre ord: det var Langes store fortjeneste, at han så tidligt som i 1909 turde formulere krav, som for sin tid var meget ambitiøse, men som ikke desto mindre blev ledestjerner for bogsamlingssagens og senere folkebibliotekssagens pionerer.

\section{Organisationen}

Længe før organisationsteoriens indtog i det moderne samfund gjorde H. O. Lange sig grundige overvejelser over, hvorledes biblioteksvæsenet i Danmark burde organiseres i fremtiden. Emnet har været beskrevet $\mathrm{i}$ andre sammenhænge, og derfor opregnes i det følgende alene hovedpunkterne i Langes overvejelser med henblik på at påvise sammenhænge $\mathrm{i}$ forhold til vor tids biblioteksvæsen. 
Først og fremmest opfattede Lange biblioteksvæsnet anno 1909 som usammenhængende og fragmenteret, hvilket ikke var hensigtsmæssigt set $\mathrm{i}$ et overordnet nationalt perspektiv, dvs:

"Det som tiltrænges for hele Landet, er en Biblioteksorganisme, der kan sprede sit Net ud over By og Land, gøre propaganda for den gode Læsning, vække og tilfredsstille Trangen til Kundskab og skabe Aandskulturen nye Vilkaar i vort Folk."

Bibliotekssagen trængte altså til organisation, men ikke med laveste fællesnævner som rettesnor. Tværtimod "er det bedste ikke for godt", hvilket jo også, som Lange udfordrende udtrykte det, netop var "vor Opgave ved disse Dages Forhandlinger", nemlig "just at finde det bedste." Men hvad var så i grunden det bedste?

Det var Langes vision, at gabet mellem de statslige, videnskabelige biblioteker på den ene side, og folkebogsamlingerne på den anden side, udfyldtes med et offentligt centralbibliotek i hvert af de daværende 18 amter, som var en i forvejen kendt administrativ inddeling af landet. Disse centralbiblioteker burde "varetage deres Oplands Biblioteksbehov i videste Omfang og sigte baade paa den mere elementære og paa den højere Læsning". Desuden skulle de være forsynede med læsestuer, hvor "under betryggende Forhold ogsaa saadanne Sager fra de videnskabelige Biblioteker kunne benyttes, der ellers ikke kan forsendes, og de maa tjene som Mellemled mellem Studerende og de store Biblioteker og som lokale Oplysningsbureauer for alle videbegærlige Mennesker inden for deres Kreds." I de større byer kunne centralbibliotekerne så i øvrigt erstatte folkebogsamlingerne, og desuden være centrum for udlånsfilialer.

Centralbibliotekets bestand på "indtil 50.000 Bind" skulle både rumme "underholdende og belærende Litteratur", og på læsestuen med "Haandbibliotek" skulle der forefindes "Blade og Tidsskrifter og tidssvarende Kataloger". Udvalget af bøger skulle foretages af bibliotekarer, der skulle være "kræsne i Valget", og centralbibliotekerne, som også benævntes "Provinsbiblioteker", skulle have "det bedste og nyeste af nordisk Litteratur, der meddeler Kundskab og Oplysning, og det bedste af den Litteratur, der beriger Aand og Hjerte", men også "Værker paa fremmede Sprog, valgte med Omhu og Forstand. Bøgerne skulle udlånes til oplandet, men cen- 
tralbiblioteket skulle også udsende "Vandrebiblioteker overalt, hvor saadanne ønskes" og "det indretter særlige Skolebogsamlinger, der kan veksle."

Det var vigtigt for Lange at understrege, at centralbiblioteket bemandedes med "det bibliotekariske Initiativ inden for sit Omraade og arbejder hen til Oprettelsen af Haandbiblioteker i Landsognene". Samtidig skulle centralbiblioteket tage udgangspunkt i de lokale forhold, "f. Eks. de lokale Industrier eller en særlig Art højere Undervisning, der har sit hjemsted i Byen." Om centralbibliotekets overordnede formål anførte Lange, at dets opgave var "paa enhver Maade at tjene Samfundslivet og dets Aandsside i det lokale Samfund, at give alle samme Ret og Adgang til de Skatte, som Bøgernes Verden rummer."

Som et godt eksempel på, hvad det egentlig var Lange forestillede sig, fremhævede han Statsbiblioteket i Århus, som burde overtage " de bestaaende Folkebiblioteker" i byen, selvom det ville byde på vanskeligheder, der dog "sikkert kunne overvindes". Det ville "blive en Ære" for kommunen, hvis den ville "gaa i Spidsen for Afskaffelsen af "Folkekøkken-Biblioteket", som Overlærer Steenberg saa træffende har kaldt det herskende System, og skabte det moderne offentlige Enhedsbibliotek efter amerikansk Mønster." Desuden ville det være passende, når staten havde investeret midler til etableringen af Statsbiblioteket, at kommunen ydede "særlige Ofre" i "Bibliotekssagen".

Det var væsentligt for Lange, at hele landet fik et ensartet biblioteksvæsen, hvor både befolkningen på landet og i byen blev tilgodeset med et ensartet bibliotekstilbud, og på mange måder gjorde han op med især bogsamlingskulturen i landkommunerne, der "jo nu i ret stort Omfang har deres Folkebogsamlinger". Disse var han imidlertid skeptisk overfor:

"I mine Tanker er der i vore Dage ikke megen Mening $i$ at have en permanent lokal Samling af underholdende Litteratur $i$ et Landsogn; de gode Bøger i vor underholdende Litteratur bliver jo billigere og billigere."

I stedet skulle de førnævnte "Haandbiblioteker" erstatte folkebogsamlingerne, knyttet til læsestuer, der "de fleste Steder vil kunne 
mødes af Vandrebogsamlinger, og saadanne vil vistnok, anbragte paa de rette Steder, i høj Grad kunne gøre Propaganda for god Læsning." En vandrebogsamling "af en bestemt Karakter sammenstillet og tilsendt fra Amtsbiblioteket" kunne så erstatte den eksisterende folkebogsamling, og på den måde ville "Landbefolkningen i Virkeligheden kunne faa Adgang til en langt større Litteratur, end de smaa lokale Folkebogsamlinger nu byder dem."

Det nye centralbibliotek, også benævnt "Amtsbibliotek", skulle imidlertid ikke drives af staten eller amtet, men derimod være "det lokale Samfunds Ejendom og kun komme sit Opland til gode" og således være selvejende. Argumentet for den lokale forankring var, at der så ville opstå "den rette Vekselvirkning mellem den følbare Nytte, som det gør, den lokale Interesse, det lokale og private Initiativ, der er af langt større Værdi end Statens Initiativ i en Sag, som denne, og endelig de lokale Ofre." Derimod skulle staten træde til, hvis det lokale incitament til at drive et bibliotek svigtede.

Visionen kunne imidlertid kun realiseres under forudsætning af, at staten skabte en "organisatorisk Grundvold" gennem en bibliotekslovgivning, hvor kommunerne fik ret til at opkræve en slags biblioteksskat til "Bibliotekssagens Fremme" efter krav fra de stemmeberettigede. Atter henvistes til udviklingen i "de angelsaksiske Lande", hvis bibliotekslovgivninger havde været "af den allerstørste Betydning for Bibliotekssagens Udvikling." En kommission skulle derfor nedsættes med henblik på at formulere lovens ord, og Lange forventede, at et lovforslag ville "faa en god Modtagelse af vore Lovgivningsmyndigheder", for som han udtrykte det: "de har jo altid vist saa stor Forstaaelse for sociale Opgaver." Endvidere var det naturligt med en bibliotekslovgivning, akkurat svarende til skolelovgivningen i Danmark, hvor skolevæsenet var lokalt forankret, men understøttet af staten. Statens væsentligste direkte opgave skulle være, at understøtte centralbibliotekerne økonomisk ved først og fremmest at dække dele af udgiften til ansættelsen af en professionel, "selvstandig, uddannet Bibliotekar" mod til gengæld at fă "Ret til Tilsyn med Biblioteket og til Kontrol med dets Ledelse i rent teknisk Henseende". Desuden skulle biblioteket indsende en årlig beretning om virksomheden til staten, hvis hidtidige "Statens 
Komité for Folkebogsamlinger" skulle erstattes af et "Biblioteksraad, der kan yde Administrationen sagkyndig Hjælp og fremhjælpe et stadigt og rationelt Samarbejde med de store Statsbiblioteker."

At staten skulle inddrages betød imidlertid ikke, at det hidtidige private initiativ, især manifesteret gennem de mange private folkebogsamlingers aktiviteter, skulle ophøre, idet bibliotekssagen i sig selv hovedsageligt blev båret oppe af enkeltpersoner, der bar den frem i lokalsamfundet. Disse kunne så passende danne amtslige biblioteksforeninger, der kunne støtte centralbiblioteket og samtidig kunne medlemmerne virke som ambassadører for sagen og propagandere herfor, "ikke mindst ved de Lejligheder, da der kan lægges et moralsk Pres paa de lokale autoriteter i Retning af forøget økonomisk Hjælp."

Udgifterne forbundet med driften af et centralbibliotek i amtet ville opvejes gennem en "umiddelbar Nytte" af det. Lange fremhævede, at byen, som husede den nye institution, ville "komme til at huse en social Kraft af uendelig Rækkevidde, af den største Betydning baade for Byens Erhvervsliv og dens Aandsliv." Biblioteket skulle også have egne lokaler, enten placeret i en eksisterende eller en særlig bygning opført og indrettet specielt til biblioteksformål.

Alle kræfter i byen ville få glæde af det frie offentlige bibliotek, som ifølge Lange var "den mest demokratiske Institution, der gives, og er mere end andre rene Kulturopgaver egnet til at forene alle Kræfter til fælles Ofre for at sikre Byens Beboere et saadant Gode" og der kunne "gøres Prøve paa, hvad Værdi Aandskulturen har for en Bys Befolkning, naar der bliver tale om at ofre noget for det frie offentlige Bibliotek." Især appellerede Lange til kvinderne i kommunalbestyrelserne, idet han mente disse havde særlige forudsætninger for at forstå betydningen af bibliotekssagens fremme.

Bibliotekssagens fremme var ikke alene et spørgsmål om, at ildsjæle talte varmt for bøgernes betydning for samfundet og agitation for læsningen. Med udgangspunkt i biblioteksforholdene i Amerika fandt Lange det hensigtsmæssigt, at man i stedet for at fokusere alene på bøger og lokalet, sådan som det var tilfældet i Danmark, rettede blikket mod fire faktorer $\mathrm{i}$ en prioriteret orden, dvs. bibliotekaren, bøgerne, "Arbejdsmetoden" og lokalerne. For Lange var 
bibliotekaren den allervigtigste nøgle til biblioteksudviklingen i Danmark, og selvom han respekterede "Amatøren" var hans tale en indvarsling af en ny tid, hvor en egentlig bibliotekarisk profession så dagens lys.

Den uddannede bibliotekar måtte aflønnes, men samtidig måtte denne også føle sig kaldet til arbejdet:

"Den rette Mand vil ikke blot sige Manden med de tilstrækkelige Kundskaber - ja Kundskaber kan en Biblioteksmand jo aldrig faa nok af - men ogsaa Manden - eller Kvinden - med det rette Syn paa Opgaven, med "the library spirit", der forstaar Bøgernes Mission, der ikke er Bibliotekar for at leve, men lever for at være Bibliotekar, der forstaar de forskelligste Menneskers Tankegang og sætter en Ære i at hjælpe dem, der altid har Bibliotekets Ve og Vel paa Hjerte, der forstaar at smitte andre med sin Begejstring, der forstaar at gaa i Spidsen uden at ville regere og dominere, der sætter en Ære $i$ at faa sine gode Idéer gennemført, uden at man mærker, at han er Fader til dem. Der er ingen Grænser for, hvad et saadant Menneske kan udrette i det lokale Samfund, hvis aandelige Vel han skal tjene. Han kender sin Bogsamling, han ved, hvad hans Bøger kan svare paa, og han vil sætte en Ære i, at enhver, der spørger, faar et Svar; han vil gøre Bibliotekssagen aktuel i Befolkningen og være dens Missionær i tide og Utide. Han vil gøre et lille Bibliotek i nogle Stuer i Baggaarde til en Aandsmagt, hvis Virkninger kendes i vid Omkreds, og jeg tænker, at en skøn Dag flytter han sine Bøger hen i en egen Bygning, som er blevet baade en Nødvendighed og en Selvfølge."

Altså var bibliotekarens arbejde ikke længere at regne for en "Bibeskæftigelse", men derimod en beskæftigelse, som burde aflønnes blandt andet gennem statslige tilskud, suppleret med midler fra amter og kommuner. Samtidig stod det klart for Lange, at bibliotekssagens fremme stod og faldt med, at den rette person kom til at lede arbejdet. Foruden at være professionel skulle lederen ikke opfatte sig som "Enehersker", men derimod tjene biblioteket "som det lokale Samfunds Ejendom" og dets bestyrelse, der skulle repræsentere "de forskellige Faktorer, der bærer Biblioteket." Bestyrelsen skulle til gengæld være "effektiv, ikke blot Bestyrelse af Navn" og ansvarlige for driften, herunder økonomien, med en bestyrelses- 
repræsentant som kasserer. Valget af bibliotekar skulle foretages af bestyrelsen, men ansøgerens kvalifikationer skulle forinden være bedømt af ministeriet. Samtidig lagde Lange vægt på, at bestyrelsen skulle bestå af "indsigtsfulde, upartiske og energiske Mænd og Kvinder med en virkelig Forstaaelse af Bibliotekssagens Betydning", og med repræsentanter for offentlige og lokale interesser, herunder en repræsentant for "de højere og lavere Skoler".

I forlængelse heraf fandt Lange det for særdeles væsentligt, at borgerne fik adgang til litteraturen. Det var ikke manglen på bøger, som var et problem i landet, men snarere den manglende tilgængelighed til bøgerne, og "Ulykken er, at de enten findes i lukkede Biblioteker, der ejes af foreninger, eller i døde Biblioteker, hvor Folk ikke kan finde dem, eller hvor det er besværligt at faa fat i dem". Målet i fremtiden måtte derfor være, at bibringe befolkningen en forståelse af, at "de har Ret til Bøgerne", hvilket blandt andet skulle sikres ved et gratis bibliotekstilbud. Samtidig understregede Lange, at bogsamlingerne - eller bibliotekerne om man vil - ikke fik karakter af museer, men derimod havde en aktuel værdi for borgerne, og selv det mindste bibliotek skulle "kunne rumme alle den danske Litteraturs Perler og en Samling af den bedste oplysende Litteratur i vort Sprog." Desuden skulle bøgerne cirkulere og lokale foreninger, f. eks. "en Afholdsforening" og lokale læsekredse inddrages i bibliotekets virksomhed.

Altafgørende for realiseringen af Langes organisationsplan for den fremtidige biblioteksudvikling var, at de statslige og stedlige tilskud blev forvaltet mest hensigtsmæssigt, men så længe den hidtidige organisation bestod, dvs. med et spredt biblioteksbillede præget af mange små folkebogsamlinger spredt omkring i landet, skulle statstilskuddet bevilges som hidtil. Hvis Langes plan skulle føres ud i livet betød det, som anført i hans foredrag, at den fremtidige statslige støtte alene skulle bevilges til amtsbibliotekerne, som samtidig skulle drive "Haandbiblioteker paa Landet", mens "den underholdende Litteratur kan faas som Vandrebiblioteker fra Amtsbiblioteket.” For de større byer, som ikke kunne få et amtsbibliotek oprettet, skulle de lokale myndigheder yde et tilskud, suppleret med midler fra staten til afholdelse af lønudgifterne. 
Sammenfattende kan Langes vision i korte træk beskrives således:

Opbygningen af et enstrenget og sammenhængende biblioteksvæsen, hvor alle borgere i princippet fik mulighed for at låne bøger fra alle offentlige biblioteker, og hvor bøger fra de største biblioteker, dvs. de statslige, udlåntes til de mindste enheder i et hierarki bestående af:

De statslige biblioteker

Amtsbiblioteker og filialer heraf

Biblioteker i de større byer

Håndbogsamlinger på landet og i de mindre bysamfund Vandrebogsamlinger på landet

Selvom Lange betegnede sig selv som hørende til blandt "pessimisterne" blandt biblioteksfolkene, fandt han alligevel positive træk i udviklingen, fordi større kredse i befolkningen efterhånden havde indset, at bibliotekerne gjorde nytte $i$ en kultur, som " $i$ saa mange Henseender er baade overfladisk og hul", hvor "vor Fremtid er truet og fuld af Farer". Han så frem til fremskridt i bibliotekssagen, og håbede at man fra samfundets side ville "til at grave dybt i Grunden for at bygge vor nationale og kulturelle Fremtid", thi:

"Et lille Land maa samle sin Kraft om Kulturvirkeligheder og om det Kulturarbejde, der kræver Ofre. Kulturlivets Skum og Gøgl hidser og beruser, undergraver Viljen og slapper Karakteren. Det er Arbejdet for at løfte og øjne, for at rense og uddybe, der bringer Folkeheld i Nutid og Fremtid."

\section{Reaktionerne}

I den efterfølgende diskussion på biblioteksmødet fik Lange fuld opbakning til sin vision om etableringen af et sammenhængende biblioteksvæsen i Danmark. Deltagerne i mødet bakkede Lange op, og Steenberg indledte med at ytre følgende: "Jeg kan i det hele slutte mig til Overbibliotekar Langes Forslag", og supplerede med at nævne, at han på den foregående generalforsamling i Foreningen Danmarks Folkebogsamlinger selv havde foreslået, at denne organi- 
serede sig i forhold til amterne. Dermed var Langes tanke om en amtslig organisering af de lokale bogsamlinger ikke fjern fra virkeligheden. Derimod var der fra Steenbergs side skepsis med hensyn til Langes ideer om, at reducere bestanden af bøger i sognebogsamlingerne, således at de reelt kunne ende som rene håndbogsamlinger. Det ville ikke være i bogsamlingssagens interesse, hvis udlånet ikke var muligt lokalt, idet de unge læsere dermed ville være afskåret fra en direkte og nær kontakt til folkebogsamlingerne.

Også højskolelæreren Poul Bjerge, Askov, var begejstret og kaldte foredraget for "Fremtidsmusik", og han roste Lange for at have holdt sit foredrag "ikke alene med Dygtighed, men med en Varme, saa det greb os alle, og vi følte, at Musikken laa ikke langt ude i Fremtiden." Samtidig hæftede han sig ved, at bibliotekssagen nød fremme mange steder, både i Kultusministeriet og ude blandt befolkningen, f. eks. i det danske foreningsliv. For Bjerge var det en forudsætning, at visionen blev fremmet gennem agitation, og han efterlyste en plan hos Lange, som bogsamlingssagens støtter kunne arbejde efter.

Statsbibliotekets overbibliotekar Grundtvig takkede for foredraget, som han kaldte "æggende" og fremført med "saa stor Varme". Hans bekymring var, at en eventuel biblioteksbestyrelse ville være en hæmsko i bibliotekarens daglige arbejde og således berøve denne "det frie Initiativ". Desuden tilsluttede han sig ønsket om, at fă reduceret antallet af "vore urimelig mange Foreningsbogsamlinger", hvis bestande i stedet kunne gøre mere gavn, hvis de administreredes af $\mathrm{f}$. eks. Statsbiblioteket.

Det fremgik også af diskussionen, at Langes vision for en samlet biblioteksorganisation havde lange udsigter, ikke mindst i henseende til spørgsmålet om finansieringen, hvor mulighederne for en skattefinansieret model var begrænsede, og en direkte skatteudskrivning, altså en slags biblioteksskat var ikke at foretrække, og ville heller ikke have politisk opbakning, hvilket Raphael Meyer påpegede i sit indlæg, men i øvrigt appellerede til, at de tilstedeværende ville "tilsige Lange deres Støtte."

Bogtrykker Klixbüll, Kolding, udtrykte egentlig på udmærket vis det, som var realiteterne for bogsamlingsfolkene i 1909, nemlig den 
kendsgerning, at de ofrede sig for en sag, der var vokset op nedefra som en slags folkesag, og derfor arbejdede "under smaa Forhold" og "med smaa Midler". Derfor måtte de koncentrere sig om nære mål og i øvrigt "selvfølgelig under fuld aandelig Frihed". Det betød dog ikke, at Langes forslag ikke skulle nyde fremme, og Klixbüll fortsatte: "Det glædede mig at høre Lange fremsætte et bestemt Forslag, paa hvis Virkeliggørelse vi nu skal til at arbejde.Vi trænger til Midler til det Selvarbejde, som skal uddybe de Interesser, den spredte Virksomhed har vakt." Imidlertid var det ikke tilstrækkeligt alene at arbejde på eget initiativ, men derimod nødvendigt at inddrage "Højskolen og alle de Oplysningsvirksomheder, som er groet op i dens Spor, og i Forening med dem rejse et Krav, der kan naa Bevillingsmyndighederne."

I sin sammenfatning af diskussionen understregede Lange, at han ikke havde noget imod små biblioteker, men deres styrke lå i formidlingen af "den underholdende Litteratur". Med hensyn til en skattefinansiering fandt han, at den kun skulle finde sted, hvis befolkningen vitterlig bakkede op om bibliotekssagen, idet "en Befolkning, der ikke vil have Bøger, fortjener heller ikke at faa dem." En farbar vej til en skattefinansiering ville efter Langes opfattelse være, at "benytte os af Lysten til Konkurrence mellem Byerne og søge at faa dem til at overgaa hinanden med at give Tilskud.” På dette punkt skete på længere sigt, det som Lange fandt ønskværdigt, nemlig at benytte belønningen som incitament til at udvikle folkebibliotekerne. Netop belønningen for at foretage forbedringer af standarden på landets folkebiblioteker viste sig at bære frugt, idet øgede lokale tilskud til forbedringer i kvaliteten samtidig førte til højere statstilskud. Samtidig anerkendte han det frivillige arbejde, som lå til grund for folkebogsamlingernes virke: "De mænd, der har baaret denne Sag frem, og som begejstret har gjort det frivillige Arbejde, de hører hjemme i de nye Bestyrelser; det at vække den lokale Interesse hænger sammen med det lokale Selvstyre." Det betød dog ikke, at lederen af biblioteket skulle lade sig undertvinge bestyrelsen, men snarere havde en stor "Opgave med diplomatisk Forstaaelse og Visdom at "opdrage" Biblioteksbestyrelsen", hvilket ikke var en "haabløs Opgave, men en taknemelig Opgave", thi: 
"Det er ideelt at ville gaa i Spidsen og faa sine Ideer gennemført uden selv at ville have Æren derfor."

Lange fik det sidste ord og understregede betydningen af fortsat og styrket agitation for det, som siden hen skulle blive til bibliotekssagen. Selv havde han ikke kræfter til at farte land og rige rundt $\mathrm{i}$ agitationens tjeneste, men foreslog $\mathrm{i}$ stedet, at hans foredrag blev trykt, hvilket også skete efterfølgende, og omdelt til kommunalbestyrelsesmedlemmer og andre med interesse for sagen. Desuden skulle andre også bidrage til en agitation blandt andet gennem Bogsamlingsbladet. Som en værdig slutsten på hans foredrag foreslog Lange vedtagelsen af en resolution, som blev vedtaget på Danmarks første biblioteksmøde i enstemmighed. Heri henledte mødet "det høje Ministeriums Opmærksomhed paa Nødvendigheden af en omfattende Organisation af vore Biblioteksforhold", og man anmodede om, at "denne Sag tages under alvorlig Overvejelse, om muligt i en Kommission".

\section{Biblioteksmodets afslutning}

Efter to travle, men også inspirerende dage afsluttede Grundtvig Danmarkshistoriens første biblioteksmøde med at konstatere, at emnerne, der havde været drøftet "dog alle er af stor Betydning". Han håbede, at deltagerne havde "haft noget Udbytte af disse Dage" og måtte "have Lyst til at mødes igen ad Aare." Det var arrangørernes håb, at "saadanne Sammenkomster burde blive en fast Institution" og derfor var de "villige til at forberede det næste Møde", hvilket ikke mødte nogen indvendinger og Grundtvig betragtede derfor "Forslaget som vedtaget", og ytrede håb om, at "vi maa mødes igen om ikke alt for lang Tid."

Herefter fik deltagerne en omvisning på Statsbiblioteket og senere på aftenen mødtes en lille kreds, dvs. 33 deltagerne, "deraf flere med deres Damer" til "en tvangfri Sammenkomst med Fællesspisning i Folkeparkens Restaurant", som "Mødets eneste selskabelige Samvær", idet dårligt vejr umuliggjorde en "paatænkt Udflugt om Tirsdagen med Dampbaad til Varna og Ørnereden". Spisningen forløb, som det anførtes i Bogsamlingsbladets mødereferat, "i enhver Henseende fornøjeligt og spaaede, ligesom Mødet selv, godt 
for fortsat frugtbart Arbejde - og Samarbejde for Bibliotekssagen i Danmark."

Spådommen gik i opfyldelse, om end der ikke altid var tale om et gnidningsløst samarbejde mellem de forskellige interesser i dansk biblioteksvæsen, så må biblioteksudviklingen set $\mathrm{i}$ et 100 års perspektiv karakteriseres som præget af "frugtbart Arbejde".

Perspektivering: Det forste biblioteksmødes betydning for eftertiden Det første danske biblioteksmøde blev begyndelsen på en ny æra i dansk bibliotekshistorie. I 1909 tog en ny epoke sin begyndelse. Bogsamlingssagen var langsomt ved at rinde ud, for at blive afløst af "bibliotekssagen". Afholdelsen af biblioteksmødet blev begyndelsen til en ny tradition, idet årlige biblioteksmøder fulgte efter. Foreningen Danmarks Folkebogsamlinger benyttede biblioteksmøder internt til drøftelser af biblioteksfaglige og - politiske anliggender og udadtil, som en agitationsform. De udadrettede biblioteksmøder rundt om i landet nød stor folkelig opbakning og medvirkede til at gøre bibliotekssagen til en folkesag. Også i forhold til samarbejdspartnere i udlandet fik biblioteksmødet som forum for udveksling af ideer og synspunkter stor betydning. I 1918 afholdt Dansk Biblioteksforening et biblioteksmøde med nordisk deltagelse. I 1926 afholdtes det første egentlige og selvstændige nordiske biblioteksmøde i Danmark og i årene op til 2. verdenskrig fandt biblioteksmøder i nordisk regi sted på skift mellem landene. Efter verdenskrigens afslutning fortsatte de fælles nordiske biblioteksmøder med års mellemrum, og også de anglo-nordiske biblioteksmøder bør fremhæves her som eksempler på, at sådanne møder fremmede dialog og samarbejde blandt biblioteksfolk og andre med interesse for biblioteksspørgsmål. Årsmøder i Danmarks Biblioteksforenings regi er en tilbagevendende begivenhed, lige som en række andre biblioteksfaglige organisationer afholder fælles møder for deres medlemmer efter samme model, som biblioteksmødet i 1909.

Betydningen af det første biblioteksmøde var imidlertid mere end blot det, at skabe grundlaget for en ny, men også meget vigtig tradition. Biblioteksmødet gav resultater på kortere, men også længere 
sigt. Eftertidens vurderinger heraf har først og fremmest - og det med rette - været præget af navnlig Langes foredrag, som var epokegørende, banebrydende for nytænkning og visionært, idet dansk biblioteksvæen $\mathrm{i}$ dag netop har en biblioteksorganisation, som i hovedtræk svarer til, hvad der blev betegnet som "Fremtidsmusik" i 1909. Som kronen på værket må oprettelsen ved indgangen til det 21. århundrede af www.bibliotek.dk som fælles national portal for det danske biblioteksvæen siges at være en endelig opfyldelse af $\mathrm{H}$. O. Langes vision om en samlet dansk biblioteksorganisation ${ }^{7}$.

Alligevel er der mange ting, som stadig påkalder sig opmærksomhed i ønsket om, at fremme biblioteksudviklingen i sin helhed og ses biblioteksmødet i 1909 i det perspektiv, ja så må hele biblioteksmødets forløb karakteriseres som meget vigtigt og betydningsfuldt, idet de mange foredrag og diskussioner i løbet af de to mødedage tog emner op til debat, som diskuteredes dengang, men som så sandelig stadig drøftes den dag i dag.

\section{Epilog}

Biblioteksvæsenet $\mathrm{i}$ dag er fortsat vigtigt også $\mathrm{i}$ forhold til demokratiet. Dette understreges af, at bibliotekerne nyder stor og i reglen positiv bevågenhed blandt politikerne. De anerkendes som vigtige for et demokratisk samfund, hvorfor en ofte tilbagevendende debat om betaling eller ej for kerneydelserne falder til jorden med argumentet om, at der også af hensyn til demokratiet skal være fri og lige adgang for alle til de offentlige og skattefinansierede biblioteker. Samtidig sikrer bibliotekslovgivningen, at offentlige informationer stilles til befolkningens rådighed, og i øvrigt henvises borgerne ofte til bibliotekerne, når de ønsker information om sager, der er aktuelle i den offentlige debat. På biblioteket stilles materialer til rådighed, der kan belyse en sag fra flere sider. Dette var en af målsætningerne på biblioteksmødet for 100 år siden, og den er stadig gældende i dag. 


\section{NOTER}

1. H. O. Lange (1959); Hvenegaard Lassen, H. (1962); Allerslev Jensen (1985); Dyrbye et al. (2005)

2. Dyrbye (2005), s. 229-248; Dyrbye et al. (2005), s. 45-83

3. Hvenegaard Lassen (1962), s. 116-124; Dyrbye et al. (2005), s. 70-71; RA Arkivnr. 2073. Pakke 10.

4. Med mindre andet er angivet, er hovedkilden i det følgende Beretning om Biblioteksmødet i Aarhus den 3. - 4. August 1909 optrykt i Bogsamlingsbladet, 4. årg. 1909-1910, s. 73-97.

5. H. O. Langes foredrag blev gengivet $\mathrm{i}$ en lidt forkortet udgave i Beretning om Biblioteksmødet i Aarhus den 3. - 4. August 1909, optrykt i Bogsamlingsbladet, 4. Årg. 1909-1910, s. 87-91. Hele Langes foredrag, hvorfra citaterne i det følgende er hentet, optryktes i Bibliotekarforeningens Smaaskrifter. H. O. Lange: Bibliotekssagen udenfor København. Foredrag paa Biblioteksmødet i Aarhus d. 4. August 1909. København 1909.

6. Her citeres, jf. note 4, Beretning om Biblioteksmødet i Aarhus den 3. - 4. August 1909 optrykt i Bogsamlingsbladet, 4. årg. 1909-1910, s. 73-97.

7. Dyrbye et al. (2005)

\section{LITTERATUR}

Allerslev Jensen, Erik: "Til Bibliotekssagens Fremme". Træk af Bibliotekstilsynets Virksomhed indtil 1970. Edvard Pedersens Biblioteksfond: København, 1985

Dyrbye, Martin: Foreign Influence on the Development of the Danish Public Libraries with Emphasis on the Association Denmark's Popular Book Collections, 1905-1919. New Frontiers in Public Library Research edited by Carl Gustav Johannsen and Leif Kajberg. The Scarecrow Press, Inc.: Lanham, Maryland; Toronto; Oxford, 2005 - s. 229-248

Dyrbye, Martin et al.: Det stærke folkebibliotek. Danmarks Biblioteksforening: København, 2005

H. O. Lange. Udgivet af Danmarks Biblioteksforening i 50-året for overbibliotekar Langes foredrag på det første almindelige danske biblioteksmøde i Århus 1909. Dansk Bibliografisk Kontor: København, 1959

Hvenegaard Lassen, H.: De danske folkebibliotekers historie 1876-1940. Dansk Bibliografisk Kontor: København, 1962 
KILDER

Lange, H. O.: Bibliotekssagen udenfor København. Foredrag paa Biblioteksmødet i Aarhus d. 4. August 1909. København 1909. Trykt i Bibliotekarforeningens Smaaskrifter.

Beretning om Biblioteksmødet i Aarhus den 3. - 4. August 1909 optrykt i Bogsamlingsbladet, 4. Årg. 1909-1910, s. 73-97.

Rigsarkivet (RA) Arkivnr. 2073. Pakke 10. 